\begin{tabular}{ccc} 
FOLI A & ENTOMOLOGICA & HUNGARICA \\
& ROVARTANI KÖZLEMÉNYEK & \\
Volume 80 & 2019 & pp. $239-246$ \\
\hline
\end{tabular}

\title{
First Hungarian records of Aprostocetus eriophyes, an acariphagous chalcidoid wasp (Hymenoptera: Eulophidae)
}

\author{
Simon HAAR DER ${ }^{1 *}$, Csaba ThuróczY ${ }^{2} \&$ György CsóKA ${ }^{3}$ \\ ${ }^{1}$ Knudsskovvej 62, 4760 Vordingborg,Denmark.E-mail:simon.haarder@gmail.com \\ ${ }^{2}$ H-9730 Köszeg, Malomárok utca 27,Hungary.E-mail: thuroczy.cs@freemail.hu \\ ${ }^{3}$ NARIC Forest Research Institute, Department of Forest Protection, \\ H-3232 Mátrafüred, Hegyalja utca 18, Hungary.E-mail:csokagy@erti.hu
}

\begin{abstract}
Aprostocetus eriophyes (Taylor, 1909) (Hymenoptera: Eulophidae) is reported as new to the Hungarian fauna. Female specimens were reared from galls of the hazelnut big bud mite (Phytoptus avellanae Nalepa, 1889) (Phytoptidae) collected in February to April 2017 at six different locations in Hungary. Diagnosis, hosts, biology and distribution of $A$. eriophyes is discussed. With 3 figures.
\end{abstract}

Keywords - Chalcidoidea, Phytoptidae, hazelnut big bud mite, new country record

\section{INTRODUCTION}

A variety of different feeding strategies have been reported to occur in the species-rich hymenopteran subfamily Tetrastichinae (Chalcidoidea: Eulophidae): species with known biology are mostly insect parasitoids, but necrophagy, inquilism and even gall-formation have been described (GrAHAM 1987, Kosheleva \& Kostjukov 2014). Other species act as predators in the larval stage - and are therefore, strictly speaking, not parasitoids - attacking eggs or larvae of host organisms such as spiders, cockroaches, nematodes, scale insects and gall mites (Graham 1987, Kosheleva \& KostJu Kov 2014).

Aprostocetus eriophyes (Taylor, 1909) belongs to the last-mentioned category: gall mite predators. It was described as Tetrastichus eriophyes from Great Britain in the beginning of the 20th century as a predator of the blackcurrant gall mite (TAYLOR 1909). It has since been recorded from a number of European countries (and Turkey) and is associated with several gall mite species (see "Distribution", "Hosts" and "Biology" for details).

In this paper, we present the first Hungarian records of $A$. eriophyes along with notes on identification, hosts, biology and distribution.

${ }^{*}$ Corresponding author. 


\section{MATERIALS AND METHODS}

Galls attributed to the hazelnut big bud mite (Phytoptus avellanae Nalepa, 1889) were collected at six Hungarian locations during winter and spring of 2017 (Fig. 1): Gyöngyös, Sárvár, Ásotthalom, Mátrafüred, Sopron and Kecskemét. The galls were kept in plastic rearing containers with ventilation lid to avoid mould. The rearings were checked biweekly, and the emerged wasps were stored in ethanol and identified using the keys provided by GRA HAM (1987). Identified specimens are deposited in the private collection of the second author and in the Hymenoptera Collection of the Hungarian Natural History Museum. Visionary Digital System ${ }^{\text {Tx }}$ was used to capture photographs.

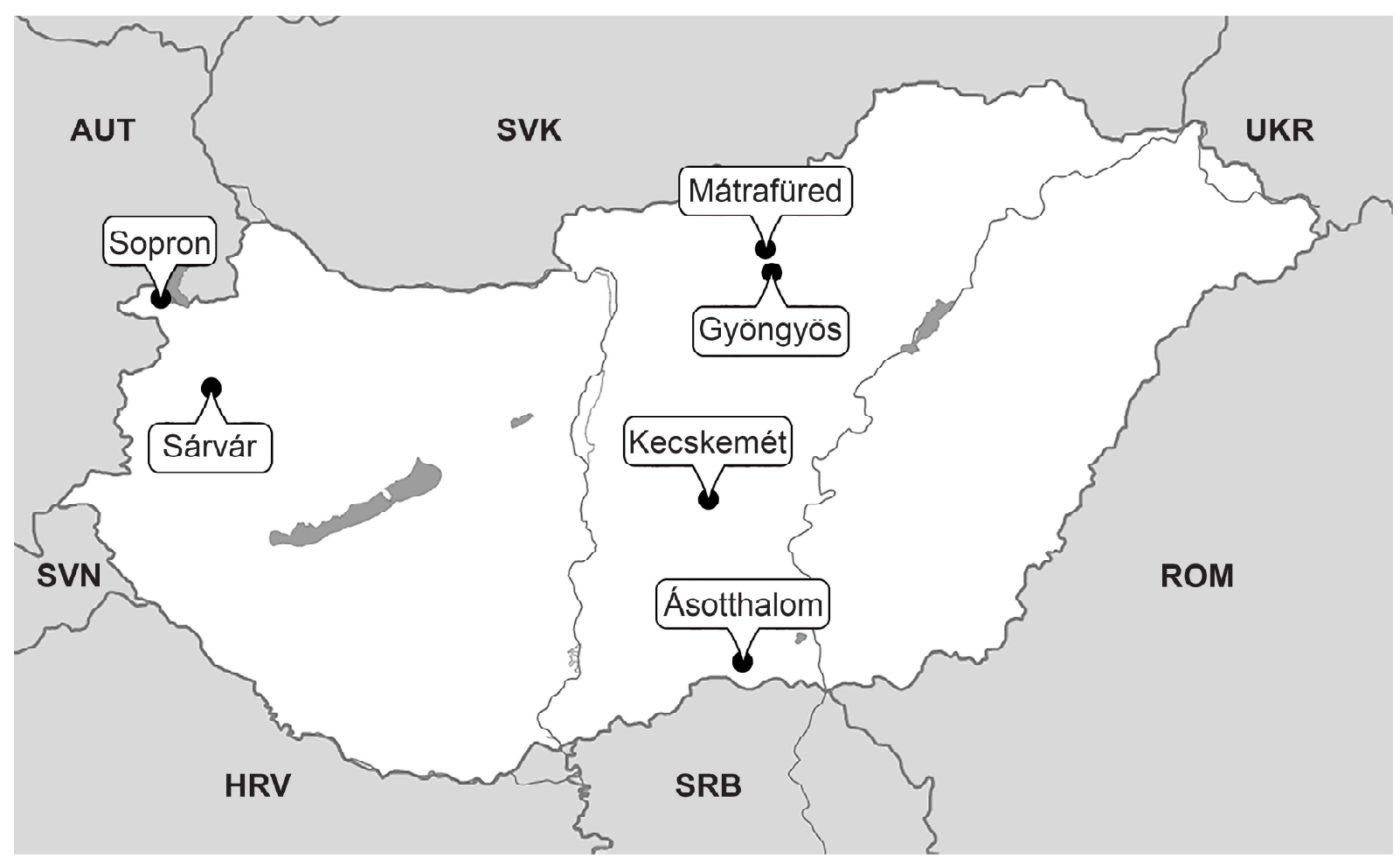

Fig. 1. Presently known distribution of Aprostocetus eriophyes (Taylor, 1909) in Hungary 


\section{RESULTS AND DISCUSSION}

Aprostocetus eriophyes (Taylor, 1909)

Material examined - Bács-Kiskun county: Kecskemét (N46.915387; E19.653990), 43 q emerged from galls collected 4.IV.2017, leg. Gy. Csóka. Csongrád County: Ásotthalom (N46.202001; E19.778293), 16 i emerged from galls collected 2.III.2017, leg. P. Andrési. - Győr-Moson-Sopron County: Sopron (N47.680279; E16.573152), 6 \% emerged from galls collected 10.III.2017, leg. Gy. Csóka. - Heves County: Gyöngyös (N47.780098; E19.929791), 53 ㅇ emerged from galls collected 17.II.2017, leg. Gy. Csóka; Mátrafüred (N47.830937; E19.969533), 13 q emerged from galls collected 3.III.2017, leg. Gy. Csóka. - Vas County: Sárvár (N47.253580; E16.943155), 9 q emerged from galls collected 2.III.2017, leg. Gy. Csóka.

Diagnosis - Short descriptions of the egg, larva, pupa and adult female were included in the original publication by TAYLOR (1909). A redescription of the species was published by MUMFORD (1931) and the larva was studied in detail by Monaco (1971). The larva can potentially be confused with the larva of Artbrocnodax coryligallarum (Targioni-Tozetti, 1887), a predatory gall midge species that is specialized on hazel big bud mites (Phytoptus avellanae). However, the two species can easily be differentiated in the larval stage as the gall midge larva is reddish, equipped with a sclerotized structure on the sternum (sternal spatula) and posseses several distinct dorsal protuberances along the body (Harris 2004, Pantaleoni \& Tavella 2006). Larvae of $A$. eriophyes are smooth, yellowish-white in colour and with reduced head morphology (MONACO 1971, Pantaleoni \& Tavella 2006, Taylor 1909). The adult female (Figs 2-3) is characterized by blackish body colour; antennae light brown; all femora at least slightly infuscate basally, blackish proximally, sometimes broadly so; tibiae yellow, sometimes hind tibia more or less blackish; fore tarsomeres brownish, mid and hind tarsi with first three tarsomeres testaceous, fourth blackish; tegulae varying from testaceous to blackish. Length 1.2-2.0 mm. Males are unknown. Within the genus Aprostocetus, A. eriopyes can be attributed to the lycidas group (GRAH AM 1987). Field-collected specimens of lycidas group need to be slide-mounted in order to accurately determine the species. However, due to the possible confusion with closely related species, only reared series of specimens will provide definite results.

The species is morphologically very close to the gall-midge parasitoid Aprostocetus pallipes (Dalman, 1820). These two species differ in length and shape of the gaster and ovipositor sheaths, but the differences are discrete and some morphological variation must be considered to occur as well. Host preference is the best way to separate the two species; $A$. eriophyes attacks gall mites on a variety of plant hosts whereas $A$. pallipes parasitizes gall midges on Betula and Salix spp. (GRAHAM 1987). Future DNA-based studies might clarify the taxonomic 
relationship between $A$. eriophyes and $A$. pallipes. Finally, another tetrastichine wasp, Quadrastichus sajoi (Szelényi, 1941), is reported to feed on gall mites in the larval stage and is originally described from Hungary. This species, however, is apparently specialised on Acalitus phloeocoptes (Nalepa, 1890) on Prunus spp. It can further be distinguished by the specific genus-characters of Quadrastichus in addition to different colour markings than those of $A$. eriophyes (GRAH AM 1987).

Hosts - The blackcurrant gall mite (Cecidophyopsis ribis (Westwood, 1869)) and hazelnut big bud mite (Phytoptus avellanae Nalepa, 1889) are the most frequently cited hosts of $A$. eriophyes (e.g. GAJE K \& BOzCEK 1998, KANERVO \& MÄKINEN 1967, ÖNCÜER 1991, ROUZES et al. 2014, TAYLOR 1909). This is probably due to more extensive investigations of pest species associated with these agriculturally important host plants. Other gall mite hosts listed in the literature include Aceria rudis (Canestrini, 1890) on Betula spp., Eriophyes tiliae (Pagenstecher, 1857) on Tilia spp. and Aceria unguiculata (Canestrini, 1891), Eriophyes buxi (Canestrini, 1891) and E. canestrinii (Nalepa, 1891) on Buxus sempervirens L. (Graham 1987, Monaco 1971). In Denmark, specimens of A. eriophyes were reared by the first author from Acalitus calycopththirus (Nalepa, 1891) on Betula pendula Roth, Aceria vermicularis (Nalepa, 1902) on Acer pseudoplatanus L. and from Cecidophyopsis psilaspis (Nalepa, 1893) on Taxus baccata L. (det. Richard Askew, France; unpublished data).

Biology - The life cycle of $A$. eriophyes has been scrutinised by several workers. One annual generation was reported by TAYLOR (1909) and GAJEK \& BoCZEK (1998) who investigated population dynamics in galls induced by the black currant gall mite in the UK and Poland, respectively. Adult females emerge from galls in May-June and subsequently oviposit into fresh galls. The larva reaches maturity the following April after nine months of development (TAYLOR 1909). In Southern Europe (Italy), two yearly generations occur in mite galls on Buxus sempervirens according to Monaco (1971). Here, adults of the first generation emerge in September-October whereas the second (hibernating) generation produces adults in June. Infestation levels also differ according to the gall mite hosts: $0-40 \%$ of mite-induced black currant galls contained $A$. eriophyes larvae (rarely more than one) in a Polish study whereas $30-40 \%$ of mite galls on $B$. sempervirens supported wasp larvae in Italy (GAJEK \& BoczeK 1998, MonACO 1971). Another Italy-based study showed that over $90 \%$ of hazel big bud mite galls contained 1-2 larvae of $A$. eriophyes (ARzONE 1985). It was also found that levels of hazel big bud mites could be naturally reduced by $A$. eriophyes and a predatory mite, Kampimodrumus aberrans (Oudemans, 1930) in insecticide-free orchards. However, several studies have shown a lack of efficacy of $A$. eriophyes in significantly reducing populations of gall mites attacking black currant (e.g. TAYlor 1909, GajeK \& BOzCEK 1998).

Distribution - Aprostocetus eriophyes is widely distributed in Europe and has been recorded from the following countries: Finland, France, Germany, the Netherlands, Italy, Poland, Sweden and the UK (Gaje \& \& Bozcek 1998, 
Gijswijt 2003, Graham 1987, Hansson 1991, Kanervo \& Mäkinen 1967, Monaco 1971, Rouzes et al. 2014, TAYLOR 1909). Eulophids reared from a number of gall mite hosts in Denmark were identified as $A$. eriophyes (det. Richard Askew, France; unpublished data) and Aprostocetus sp. specimens have recently been reared from hazel big bud galls in Norway, but a formal identification of the wasps has not been done (pers. comm. Hallvard Elven, Oslo). A. eriophyes was also found in hazelnut orchards in the Asian part of Turkey (ÖNCÜER 1991); it is specifically mentioned to be absent from commercially grown hazelnut in New Zealand (WeBber 2007).

During this study, A. eriophyes was reared from galls induced by the hazel big bud mite found at six different localities. This gall mite is very common in Hungary as is the black currant gall mite - the remaining known gall mite hosts species for $A$. eriophyes are also mentioned in the recent checklist of the Hungarian gall mite fauna except for Aceria unguiculata and A. vermicularis (RIPKA 2007, 2008). It can therefore be speculated that $A$. eriophyes is widely distributed in Hungary but has been overlooked due to the discrete feeding habit and lack of clear-cut morphological characters.

Acknowledgements - Jan Pedersen (Natural History Museum, Copenhagen, Denmark) is thanked for providing access to Visionary Digital System ${ }^{\mathrm{Tw}}$. Hallvard Elven (Natural History Museum, Oslo, Norway) provided information about Aprostocetus cf. eriophyes from Norway. Thanks to Pál Andrési (Bedő Albert Erdészeti Szakképző Iskola \& Kollégium, Ásotthalom, Hungary) for collecting sample at Ásotthalom and to Csaba Gáspár (NARIC Forest Research Institute, Mátrafüred, Hungary) for drawing the map. 


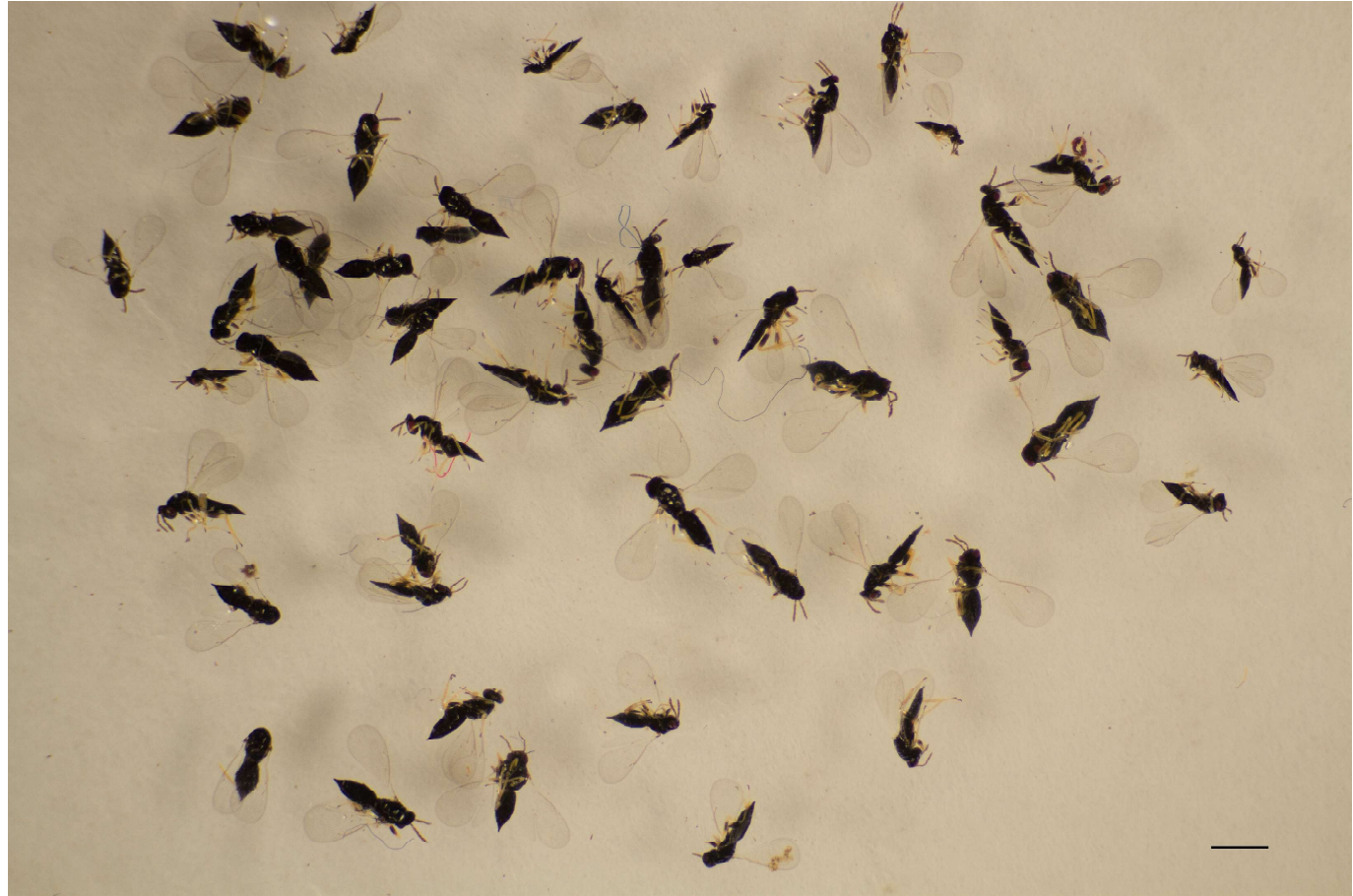

Fig. 2. Mass-rearing of female Aprostocetus eriophyes (Taylor, 1909) from galls of hazel big bud mite (Phytoptus avellanae Nalepa, 1889) collected at Gyöngyös. Scale bar $=1 \mathrm{~mm}$ (photo by Simon Haarder)

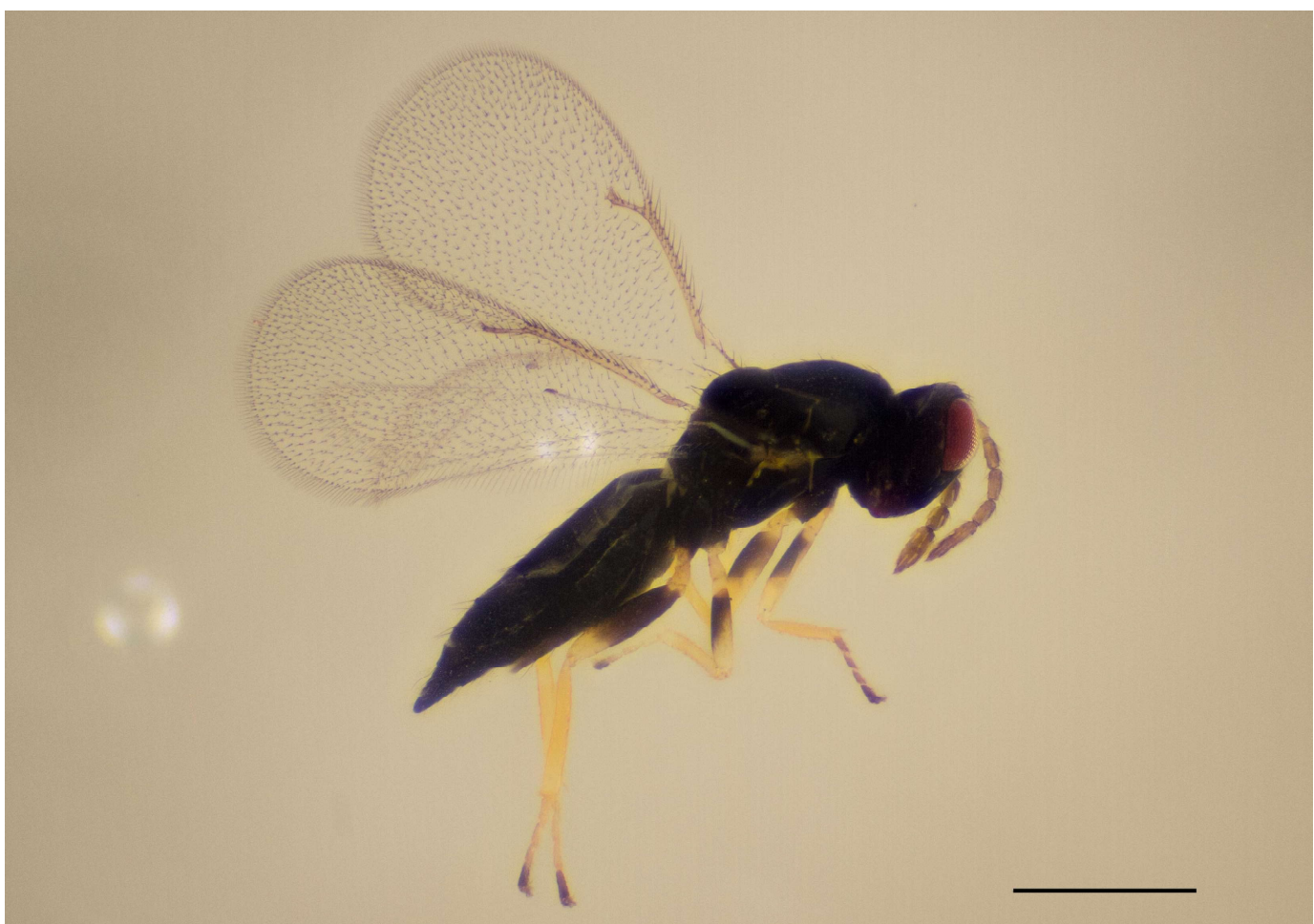

Fig. 3. Female Aprostocetus eriophyes (Taylor, 1909), habitus, from Gyöngyös. Scale bar $=0.5 \mathrm{~mm}$ (photo by Simon Haarder) 


\section{REFERENCES}

Arzone A. 1985: Due fitomizi dannosi al nicciulo: l'acaro delle gemme e il miride degli amenti. [Two plant sucking pests of hazel: the bud mite and catkin mirid.] - In: Tarantino C., D’Agostino G. \& DE Jorio F. (eds): Atti Convegno Internazionale sul Nocciuolo, Avellino, 22-24 Settembre, 1983. Istituto di Entomologia Agaria e Apicoltura, Torino, pp. 199-204.

GAJEK D. \& BoczeK J. 1998: The life cycle of the blackcurrant gall mite, Cecidophyopsis ribis Westw. (Acari: Eriophyidae). - In: Csóka G., Mattson W. J., Stone G. N. \& PRiCe P. W. (eds): The Biology of Gall-Inducing Arthropods. General Technical Report. North Central Forest Experiment Station, USDA Forest Service, St Paul, USA, pp. 131-135.

Gijswijt T. 2003: Naamlijst van de Nederlandse bronswespen (Hymenoptera: Chalcidoidea). (Checklist of the chalcid wasps of the Netherlands (Hymenoptera: Chalcidoidea).) Nederlandse Faunistische Mededelingen 18: 17-79.

GRA HAM M. W. R. DE V. 1987: A reclassification of the European Tetrastichinae (Hymenoptera: Eulophidae), with a revision of certain genera. - Bulletin of the British Museum (Natural History) (Entomology) 55(1): 1-392.

HANsson C. 1991: A catalogue of Chalcidoidea described by C.G. Thomson, with a checklist of Swedish species. - Entomologica Scandinavica 38: 1-70.

HARRIS K. 2014: British species of Arthrocnodax (Diptera: Cecidomyiidae) recorded as predators in galls of eriophyoid mites. - Cecidology 29(2): 53-58.

KANERVO V. \& MÄKINEN K. L. 1967: Tests on the control of the black currant gall mite. Maatolous Koetoim 21: 148-158.

Kosheleva O. V. \& Kostjukov V.V. 2014: Types of parasitism in eulophid wasps (Hymenoptera, Eulophidae). - Entomological Review 94(9): 1202-1217. https://doi.org/10.1134/S0013873814090024

Monaco R. 1971: Note morfobiologiche su Tetrastichus eriophyes Taylor predatore di eriofidi del bosso. - Entomologica Bari 7: 75-86.

MUMFORD E. P. 1931: On the fauna of the diseased big-bud of the black currant Ribes nigrum L. with a note on some fungous parasites of the gall-mite, Eriophyes ribis (Westw.) Nal. Marcellia 27: 29-62.

ÖNCÜER C. 1991: Türkiye bitki zararlısı böceklerinin parazit ve predator kataloğu. (A catalogue of the parasites and predators of insect pests of Turkey.) Ege Üniversiteti Ziraat Fakültesi Yayınları no. 505. - E. Ü. Ziraat Fakültesi, Izmir, 216 pp.

Pantaleoni R. A. \& Tavella L. 2006: Gli Arthropodi Utili Nei Corileti Italiani. - Petria 16(1): 135-148.

RIPKA G. 2007: Checklist of the Eriophyoid Mite Fauna of Hungary (Acari: Prostigmata: Eriophyoidea). - Acta Phytopathologica et Entomologica Hungarica 42(1): 59-142. https://doi.org/10.1556/APhyt.42.2007.1.7

RIPKA G. 2008: Additional Data to the Eriophyoid Mite Fauna of Hungary (Acari: Prostigmata: Eriophyoidea). - Acta Phytopathologica et Entomologica Hungarica 43(1): 143-161. https://doi.org/10.1556/APhyt.43.2008.1.15 
Rouzes R., Mercadal M., Ramade L. \& Guery B. 2014: Auxiliaires et autre entomofaune associes aux phytoptes du noisetier: Synthese de quatre annees d'observations. (Natural enemies and other entomofauna associated with of hazelnut big bud mites: Synthesis of four years of observations.) - In: Fougeroux A. \& Kreiter S. (eds): AFPP - Dixième Conférence Internationale Sur Les Ravageurs en Agriculture Montpellier. 22 et 23 octobre 2014. L'Association française de protection des plantes (AFPP), Alfortville, $12 \mathrm{pp}$.

TAYLOR A. M. 1909: Descriptions and life-histories of two new parasites of the black currant mite, Eriophyes ribis (Nal.). - Journal of Economic Entomology 4: 1-8.

Webber J. D. 2007: Phenology of hazelnut big bud mites in Canterbury and implications for management. MSc thesis. - Lincoln University, Lincoln, New Zealand, 126 pp. 